\title{
A gênese do interesse pela música: Trajetórias de aquisição de capitais socioculturais
}

\section{e musicais}

\author{
The genesis of interest in music: Trajectories of acquisition of sociocultural and musicals \\ La génesis del interessar por la música: Trayectorias de la adquisición de los capitales \\ socioculturales y musicales
}

\section{Resumo}

Este artigo, fruto de uma dissertação de mestrado em educação, tem por objetivo refletir sobre os capitais socioculturais e musicais incorporados, e seus impactos para o surgimento do interesse pela música, assim como, compreender as influências da família, da escola e da indústria Cultural para o referido processo. Foi feita uma pesquisa exploratória e estudo de casos múltiplos junto a dois estudantes do primeiro ano do ensino médio de uma escola de Fortaleza/Ceará. Utilizamos como aporte teórico os conceitos da praxiologia de Pierre Bourdieu - Habitus, Campos e Capitais (2009, 2011a, 2011b, 2013), da Indústria Cultural de Adorno e Horkheimer (1985) e da Cultura de Massas de Edgar Morin (2011). Através das narrativas de vida e formação musical, ficou evidenciado o papel fundamental e decisivo da família para o surgimento do interesse pela música, bem como, o auxílio e a interferência da Indústria Cultural neste processo. Por fim, a escola mostrou-se pouco participativa em tal processo.

Palavras-chave: Capitais socioculturais e musicais; História de Vida e Formação; Família-escola-indústria cultural.

\begin{abstract}
This article, the result of a master's dissertation in education, aims to reflect on the incorporated cultural and musical social capitals their impacts for the emergence of interest in music, as well as, to understand the influences of the family, the school and the Cultural industry for the referred process. An exploratory research and multiple case study were carried out with two students from the first year of high school at a school in Fortaleza / Ceará. We used as a theoretical contribution the concepts of Pierre Bourdieu - Habitus, Campos e Capitais (2009, 2011a, 2011b, 2013), the Cultural Industry of Adorno and Horkheimer (1985) and the Culture of Pasta by Edgar Morin (2011). Through the narratives of life and musical formation, it was evidenced the fundamental and decisive role of the family for the emergence of interest in music, as well as the assistance and interference of the Cultural Industry in this process. Finally, the school showed little participation in this process.
\end{abstract}

Keywords: Socio-cultural and musical capitals; History of life and education; Family-school-cultural industry.

\section{Resumen}

Este artículo, producto de una tesis de maestría en educación, tuvo como objetivo realizar una reflexión profunda sobre los capitales socioculturales y musicales incorporados, y sus impactos para la generación del interés de los alumnos por la música, así como comprender como influye la familia, de la escuela y la industria cultural en este proceso. Fue realizado una investigación exploratoria y estudio de casos múltiples con dos estudiantes del primer año de secundaria en una escuela pública en Fortaleza-Ceará Brasil. Fue usado el aporte teórico los conceptos de Pierre Bourdieu - Habitus, Campos y Capitales (2009, 2011a, 2011b, 2013), la Industria Cultural de Adorno y Horkheimer 
(1985) y la Cultura de la Pasta de Edgar Morin (2011). A través de las narrativas de vida y formación musical, se evidenció el papel fundamental y decisivo de la familia para el surgimiento del interés por la música, así como la influencia de la Industria Cultural en este proceso. Por otra parte, la escuela fue reportada como un ente que participa en menor grado en la generación de intereses por la música en los alumnos.

Palabras clave: Capitales socioculturales y musicales; Historia de vida y formación; Familia-escuela-industria cultural.

\section{Introdução}

"Fiz minhas escolhas e destas fiz minha escola, mas que contexto foi este que me permitiu escolher uma escola de calçadas e esquinas?" (Elvis de Azevedo Matos)

Este trabalho é um recorte de uma pesquisa de Mestrado em Educação, intitulada "Habitus e Formação Musical de Adolescentes: um estudo com estudantes da escola pública” de autoria de Abreu (2018), sob orientações do professor doutor Gerardo Viana Júnior, e que teve como objetivo geral compreender as influências do habitus, constituído e incorporado, na formação musical de adolescentes estudantes do primeiro ano do ensino médio de uma escola na cidade de Fortaleza, no estado do Ceará, no Brasil. Assim, apresentamos reflexões acerca da origem do interesse pela música e como a família, a escola, os amigos e a Indústria Cultural podem contribuir neste processo. Nossa análise apoiou-se na Praxiologia de Pierre Bourdieu Habitus, Campo e Capital (2009, 2011a, 2011b, 2013); nas teorias: da Indústria Cultural de Adorno e Horkheimer (1985); e, da Cultura de Massas de Edgar Morin (2011).

Através das narrativas das histórias de vida e formação musical dos sujeitos que foram entrevistados ao longo da pesquisa, identificamos alguns campos com o qual interagiram e de alguns capitais que lhe foram oportunizados em meio a tais campos, assim como, dos que herdaram da família, ou seja, dos habitus com os quais exerceram interação. Pudemos conhecer através de tais narrativas e percepções de suas histórias de vida e formação, influências por eles sofridas e capitais por eles incorporados.

O estudo foi de natureza qualitativa e utilizamos duas estratégias de pesquisa no curso das investigações, quais sejam, a pesquisa exploratória e o estudo de casos múltiplos. Compreendemos que as investigações de tal natureza partem do entendimento de que nada pode ser considerado trivial, isto é, todas as informações, fatos, acontecimentos podem constituir pistas e dados que, por sua vez, poderão auxiliar no esclarecimento do objeto estudado. (Bogdan \& Biklen, 1994)

Nosso lócus de pesquisa constitui-se no ambiente natural aos sujeitos que colaboraram com este estudo. Fomos, assim, à escola em que eles estudavam com o intuito de conhecer suas rotinas escolares e ouvir suas narrativas de história de vida, uma vez que, compreendemos que o contexto em que os sujeitos constroem suas memórias e seus processos formativos ganham relevância para a melhor compreensão do objeto de investigação. Para a coleta de dados, utilizamos como instrumentos dois questionários compostos de perguntas abertas e fechadas, entrevistas semi-estruturadas, assim como, da observação das aulas de Arte das quais os sujeitos participaram ao longo do segundo semestre letivo no curso de seu primeiro ano do ensino médio.

Como indicamos acima, utilizamos duas estratégias de pesquisa. De acordo com Gil (2009) as pesquisas exploratórias têm como finalidade desenvolver, esclarecer e modificar conceitos e ideias na busca de problemas pesquisáveis. Por sua vez, utilizamos do estudo de casos múltiplos, posto que buscamos aprofundar nossa análise e compreensão dos fatos diante dos objetivos propostos. Ainda em acordo com o autor acima citado (2009), um estudo de caso é uma busca profunda e exaustiva de um ou de poucos objetos de estudo com vistas a conhecer tais fenômenos de forma ampla e detalhada. Robert Yin (2001) defende que a principal diferença entre um estudo de caso e um estudo de casos múltiplos encontra-se, única e exclusivamente, na quantidade de unidades de análise e de casos a serem explorados. 
Destacamos ainda, que realizamos uma pesquisa descritiva. Segundo Gil (2009), "as pesquisas deste tipo têm como objetivo primordial a descrição das características de determinada população ou fenômeno ou o estabelecimento de relação entre variáveis." e, conforme Godoy (1995), "quando o estudo é de caráter descritivo o que se busca é o entendimento do fenômeno como um todo, na sua complexidade, sendo possível que a análise qualitativa seja a mais adequada.”.

\section{A praxiologia de Pierre Bourdieu, a Indústria Cultural e as Culturas de Massas}

As categorias a cultura, a indústria da cultura, a cultura de massas, a música, a educação musical, a arte na qualidade de elementos centrais para a investigação realizada. Buscamos evidenciar as "imposições" empreendidas pela família, pela escola, pela indústria da cultura, intermediada pelas culturas de massa, de capitais socioculturais, os quais foram, de certa forma, inseridos naquilo "que se pode chamar cultura, competência cultural, ou então, para evitar equívocos, habitus" (Bourdieu, 2013) circundantes aos sujeitos investigados. Bourdieu (2013) ressalta que "O habitus completa o movimento de interiorização de estruturas exteriores, ao passo que as práticas dos agentes exteriorizam os sistemas de disposições incorporadas.".

Bourdieu (2013) ressalta que o habitus é caracterizado por ser a junção de esquemas introduzidos desde a primeira educação, ou seja, a educação familiar, e constantemente repostos e atualizados ao curso da trajetória de vida dos sujeitos. Desta forma, ele estabelece que as necessidades culturais são o produto, primordialmente, da educação, e secundariamente relacionadas à origem social, sejam elas as práticas ou as preferências culturais, estando aí inserida a música (2011a).

Apoiamo-nos na análise do sistema educacional realizada por Bourdieu que revelou a existência de um intercâmbio entre os capitais herdados da família e aqueles capitais adquiridos na escola para o processo de formação. Assim, Bourdieu (2011b) alerta que "a reprodução da estrutura de distribuição do capital cultural se dá na relação entre as estratégias das famílias e a lógica específica da instituição escolar".

Assim como o habitus adquirido através da inculcação familiar é condição primordial para a estruturação das experiências escolares, o habitus transformado pela ação escolar constitui o princípio de estruturação de todas as experiências ulteriores, incluindo desde a recepção das mensagens produzidas pela indústria cultural até as experiências profissionais. (Bourdieu, 2013)

Para além dos postulados de Bourdieu, consideramos para tal estudo a teoria elaborada por Adorno e Horkheimer (1985) da Indústria Cultural, assim como, o conceito de Cultura de Massa empreendido por Edgar Morin (2011). De acordo com Morin (2011) a Cultura de Massas é a “[...] Terceira Cultura, oriunda da imprensa, do cinema, do rádio, da televisão, que surge, se desenvolve, se projeta ao lado das culturas clássicas - religiosas ou humanistas - e nacionais".

Adorno e Horkheimer (1985) afirmam que "a cultura contemporânea confere a tudo um ar de semelhança", impondo diversos capitais de cultura através de seus sistemas midiáticos - cinema, rádio, televisão, revistas, internet etc. - forçando assim, o mundo inteiro a passar pelo filtro da indústria cultural.

Assim, concebemos a hipótese de que a transmissão de capitais estaria sujeita ao intercâmbio exercido entre a família, a lógica específica da instituição escolar e as imposições culturais massivas por meio da Indústria Cultural.

A mediação operada pelo agente tendo em vista a reprodução social associa-se, segundo a mesma tradição, ao papel estratégico que o processo de socialização desempenha através das agências educativas, seja o sistema de ensino, seja os meios de comunicação de massa, seja a inculcação familiar. (Bourdieu, 2013)

O conceito de habitus tal qual proposto por Bourdieu é demasiadamente amplo e profundo. Tal teoria busca compreender e evidenciar os gostos, as atitudes, as ações e as práticas de um agente, ou ainda nas palavras do referido autor:

História incorporada, feita natureza, e por isso esquecida como tal, o habitus é a presença operante de todo o passado do qual é o produto: no entanto, ele é o que confere às práticas sua independência relativa em relação às 
determinações exteriores do presente imediato. Essa autonomia é a do passado operado e operante que, funcionando como capital acumulado, produz história a partir da história e garante assim a permanência na mudança que faz o agente individual como mundo no mundo. (Bourdieu, 2009)

Compreendemos, portanto, que o habitus é de certa forma uma espécie de modus operandi ${ }^{l}$, isto é, uma estrutura bastante abrangente de ações, de ideias, de concepções, de atitudes que comanda, de certa maneira, as atitudes e as práticas de um sujeito. Bourdieu (2011a) ainda apresenta o habitus na qualidade de "estrutura estruturante que organiza as práticas e a percepção das práticas, o habitus é também estrutura estruturada [...]”.

habitus, "sistema de disposições duráveis, estruturas estruturadas predispostas a funcionar como estruturas estruturantes, quer dizer, enquanto princípio de geração e de estruturação de práticas e de representações que podem ser objetivamente "reguladas" e "regulares" sem que, por isso, sejam produto da obediência a regras, objetivamente adaptadas a seu objetivo em supor a visada consciente dos fins e o domínio expresso das operações necessárias para atingi-las e, por serem tudo isso, coletivamente orquestradas sem serem o produto da ação combinada de um maestro". As práticas resultam da relação dialética entre uma estrutura - por intermédio do habitus como modus operandi - e uma conjuntura entendida como as condições de atualização desse habitus e que não passa de um estado particular da estrutura. (Bourdieu, 2013)

Em síntese, podemos indicar que o habitus é uma espécie de "decodificador" que habilita e auxilia um indivíduo a decifrar, ao passo que incorpora determinados capitais, a realidade em que está inserido, assim como, a compreensão de seus gostos e julgamentos. O habitus, é desta forma, uma estrutura que, ao mesmo tempo em que estrutura as práticas, colabora para a construção de uma visão de mundo sobre tal prática por um agente.

Diante do exposto, podemos inferir que o produto das práticas musicais (escuta, apreciação, execução e criação) e da percepção ${ }^{2}$ destas práticas nada mais é do que o reflexo dos capitais socioculturais incorporados pelos agentes, capitais estes inseridos em sistemas de disposições (habitus), pois, "os sujeitos sociais distinguem-se pelas distinções que eles operam entre o belo e o feio, o distinto e o vulgar; por seu intermédio, exprime-se ou traduz-se a posição desses sujeitos nas classificações objetivas." (Bourdieu, 2011).

Um outro aspecto da praxiologia de Bourdieu que estudamos é a noção de campo. Compreendemos que o campo é um espaço físico ou não físico que abriga diversos agentes que possuem capitais semelhantes, interesses afins. Com isso, queremos dizer que não existe apenas um único campo. Na verdade, devemos indicar que existem diversos campos que comunicam-se, divergem-se, ou ainda, contrapõem-se entre si.

De certa forma, o campo funciona como uma "[...] instância de inculcação [...]" (Bourdieu, 2011) de determinados capitais que podem ser adquiridos e/ou herdados, sendo estes capitais incorporados ou não a um habitus. O campo é, também um espaço social, ao qual Bourdieu assim define:

[...] o espaço social tal como foi descrito é uma representação abstrata, produzida mediante um trabalho específico de construção e, à maneira de um mapa, proporciona uma visão panorâmica, um ponto de vista sobre o conjunto dos pontos a partir dos quais os agentes comuns laçam seu olhar sobre o mundo social. (Bourdieu, 2011a)

Em sua praxiologia Bourdieu ainda nos apresenta ao conceito de capital. Capital, na perspectiva adotada pelo referido autor, diz respeito aos diversos saberes, fatos culturais, elementos capitais não restrito apenas ao conhecido capital capitalista, ou seja, o financeiro, mas sim, qualquer espécie ou forma de capital. É este capital, moeda não monetária, posso até

\footnotetext{
${ }^{l}$ Modus Operandi é uma expressão em latim que significa "modo de operação", na tradução literal para a língua portuguesa. Esta expressão determina a maneira que determinada pessoa utiliza para trabalhar ou agir, ou seja, as suas rotinas e os seus processos de realização. Disponível em: < https://goo.gl/zbNzgO>. Acessado em 25/01/2017.

${ }^{2}$ Devemos apresentar que a percepção aqui indicada não refere-se à prática de perceber auditivamente os sons ou intervalos. Na verdade, a percepção que indicamos aqui, concerne a compreensão que um indivíduo tem sobre algo.
} 
dizer moeda simbólica, que à medida que é adquirido e incorporado pelos agentes passará distinguir a posição de tal agente dentro de um campo, e uma vez estabelecido tal capital no campo, este é integrado a um habitus.

Os conceitos de capital cultural e capital social foram bastantes relevantes para este trabalho, mais especificamente o musical. Compreendemos que é potencialmente tenaz a relação entre os capitais socioculturais incorporados pelos agentes e os diferentes percursos que foram por estes percorridos ao curso de suas formações. Em face disto, foi importante compreender o que Bourdieu define como capital social, a saber:

[...] capital de relações mundanas que podem, se for o caso, fornecer "apoios" úteis; assim como capital de honorabilidade e de respeitabilidade que, muitas vezes, é indispensável para atrair ou assegurar a confiança da alta sociedade e, por conseguinte, de sua clientela, além da possibilidade de servir de moeda de troca, por exemplo em uma carreira política. (Bourdieu, 2011).

Em resumo, podemos observar que capital foi uma terminologia que Bourdieu criou para explicar como determinados elementos em uma sociedade dividida em classes podem servir como uma espécie de moeda simbólica, cujo uso pelas classes dominantes serve para perpetuar as diferenças, e, assim assegurar o seu poder sobre as demais classes.

A cultura e as relações sociais servem de ferramentas de distinção entre os sujeitos e as classes, pois, as classes dominantes impõem a todos a sua cultura, dando a ela um valor incontestável, fazendo com que seja considerada a cultura boa, tida como correta. O currículo escolar, até certo ponto, ainda é regido, criado e reproduzido a partir desses capitais. Esses capitais são, de certa forma, acentuados pela Indústria Cultural que, em grande parte, serve aos interesses das classes dominantes. No tópico seguinte apresentaremos e discutiremos alguns dos resultados da pesquisa de mestrado.

\section{A Gênese do Interesse pela Música}

A gênese do interesse pela música emergiu dos relatos de dois colaboradores, e tomou forma pela relevância que tal nascimento provocou em suas trajetórias de vida e de formação musical. Coletamos os dados e analisamos sob as lentes das teorias que alicerçam esse estudo. Conforme já apresentado na introdução, os dados que aqui apresentamos são um recorte do cômputo total das informações recolhidas durante uma pesquisa de mestrado.

A entrevistada A tem dezesseis anos de idade e residia desde seu nascimento no mesmo lugar. Foi por volta dos seis anos de idade, em forma de brincadeira, quando conheceu o instrumento musical violão na casa de seu avô, que seu interesse pela música surgiu, como nos relatou em sua entrevista: "Meu avô tinha um violão, estava com as cordas quebradas, mas eu peguei simplesmente e comecei a tocar."

Ela ainda nos revelou que, apesar de seu avô possuir tal equipamento musical, ele não sabia manuseá-lo, de modo a estar abandonado em um local da casa: "Ele não tocava. Ele tinha o violão só por estar lá mesmo. Aí eu peguei todo empoeirado e comecei a tocar.". Com o passar do tempo, e, com a ausência de manutenção, esse instrumento acabou sendo descartado "não tem mais, porque se acabou a madeira e tal, aí não tem mais".

A partir desse contato inicial com o violão, e, movida pelo encantamento que tal instrumento provocou em si, ela decide que quer aprender a tocá-lo, pois, de acordo com a informante a estrutura que tal equipamento possui, bem como, o som que ele produz lhe causa empatia, lhe proporciona prazer: "Eu acho que é um instrumento muito interessante e é um instrumento que desde criança eu quis aprender. Eu pegava assim e ficava tocando. Primeiramente chamou muito minha atenção, não só pela beleza dele e sim pela sua estrutura e som e assim me dediquei bastante ao instrumento (violão."”

Conforme já apresentado, seu primeiro contato com esse instrumento se deu aos seis anos de idade. Entretanto, seus primeiros passos em busca por aprender a tocar esse equipamento de música somente aconteceu por volta dos doze anos de idade, quando teve a oportunidade de estudar música em um projeto social que existe em seu bairro. 
Há uma distância de tempo entre o dia que conheceu o violão e o dia em que começou a aprender a tocá-lo, um período que levou cerca de seis anos. Ao ser indagada sobre o porquê de tal intervalo a entrevistada assim responde:

Porque eu percebi que aquele instrumento eu poderia, tipo assim, tocar ele. Porque muitas vezes as pessoas dizem que é dom que uma pessoa tem para tocar, e tudo, pegar o violão. Eu não. Eu já percebi por conta assim não tem curso, porque antes não tinha curso aqui de violão, era pago, e eu não tinha condições de pagar, e era muito caro, aí apareceu essa oportunidade e eu aproveitei para aprender a tocar.

Percebemos que, conforme já discutido, em sua fala a entrevistada traz elementos vinculados ao senso comum, o qual diz que poucos podem fazer música, que é algo ligado a uma predisposição natural, é um dom da natureza de um ser. É interessante perceber que a referida colaboradora levou cerca de doze anos para perceber que a falta de oportunidade para aprender música é que é, de fato, o problema, e assim, ela compreende que a música pode ser apreendida por todos.

Ainda dentro dessa perspectiva, da predisposição para a música e/ou dom musical, a informante A relata em sua entrevista desestímulos que recebeu ao longo de sua trajetória de vida e formação musical, estímulos negativos que não afetaram, de maneira veemente, seu desejo por aprender música e de ser musicista:

Quero aprender música mais e mais, até me tornar profissional. Porque muitos já me criticaram, por conta dizendo que eu não ia conseguir, que música era um blá blá blá, um nada, faz outra coisa melhor, e eu tenho em mente duas especializações para fazer que é medicina e música.

A colaboradora ainda revelou que seu desejo profissional é de seguir carreira musical, que a medicina é uma paixão que esta possui desde criança, que também fez parte de sua história de vida, sendo uma atividade lúdica que gostava de brincar em seus momentos de lazer. Quando questionada sobre o porquê ela quer estudar medicina, assim ela responde:

Medicina desde muito pequena minha mãe falava que eu gostava de ficar brincando com negócio de injeção, essas coisas assim, simples. Sempre gostava. Aí eu disse: mãe, eu acho que vou me formar em medicina, mas também tem outro em mente que é música. Até minha mãe achou até um certo tempo assim, não $\mathrm{A}$, música é sei lá, tu pode não conseguir, não dá futuro, minha mãe chegou até certo tempo falar isso. Muita gente me criticava dizendo que música... eu ia desistir de fazer música, por conta disso.

O violão não é o único instrumento pelo qual a informante A possui interesse. Tal instrumento foi o primeiro a lhe despertar desejo, entretanto, outro instrumento que esta conheceu ao curso de sua trajetória lhe despertou interesse, a saber: o teclado. Durante sua entrevista ela expõe o que motiva ela a querer estudar um outro instrumento e como ela passou a conhecer esse novo instrumento:

Como eu te falei, é praticamente a mesma coisa do violão. Eu vi, só que esse eu me inspirei por conta do meu professor, que ele tava tocando lá, eu perguntei professor é difícil tocar esse tipo de instrumento? Não A, não é difícil, basta você se dedicar a estudar ele. Aí eu cheguei até o ponto de tentar tocar com ele, ele me ensinar, só que nesse dia ele já tinha saído do projeto aí eu não tive nenhuma oportunidade de aprender não.

É importante apresentar que os dois instrumentos que a referida informante escolhe para se aproximar possuem uma relação mais íntima com o grupo de instrumentos que normalmente são utilizados em bandas de músicas populares no Brasil e, talvez, no mundo ocidental.

Assim como a colaboradora A, a entrevistada B tem dezesseis anos de idade. Durante o período de coleta de dados para esse estudo, elas habitavam o mesmo bairro. No entanto, a relação que a colaboradora B possui com o bairro e com a escola que serviu de lócus a essa investigação é bem distinta da relação que a informante A possui, uma vez que B é migrante de uma cidade do interior do estado do Ceará. 
A entrevistada B residiu a maior parte de sua história de vida e formação musical em um município cearense que tornou-se famoso pela realização de festas de vaquejada ${ }^{3}$. Esses eventos apresentam em sua programação, além das disputas entre os vaqueiros, atrações musicais que trazem em seus repertórios forró e sertanejo.

Tal informante, ao início dessa pesquisa de campo, tinha poucos meses que havia chegado ao bairro e àquela escola, estando a residir havia menos de um ano neste local.

É um tanto confusa a narrativa de tal informante acerca do surgimento de seu interesse pela música, o que torna árdua uma compreensão clara de quando surge sua relação com tal linguagem artística. Entretanto, o que falta em transparência sobre tais fatos, são evidentes na importância que essa atribui em seu cotidiano, em sua vida, uma vez que ela assim nos relata:

Música para mim é como se fosse...Passasse o dia todinho, aí quando eu vou tomar banho eu canto, quando eu estou deitada sem nada para fazer eu canto, até meu namorado reclama porque eu fico cantando direto. Porque eu não consigo, assim, estar fazendo coisa e estar assim calada, sem estar falando, sem estar cantando. Se eu estou arrumando a casa é cantando, se eu estou tomando banho é cantando, se eu estou deitada sozinha, aquele silêncio na casa, é cantando, porque eu não consigo.

Como pode ser visto no trecho da entrevista acima, a música é algo que está presente em seu cotidiano, de uma maneira forte e que representa algo que dá prazer a tal colaboradora.

A entrevistada B menciona repetidas vezes que o seu interesse pela música possui uma vinculação íntima com um fato que aconteceu em sua família. Ela, insistentemente, diz que começa a gostar de música após o falecimento de um tio seu. Entretanto, o que de fato acontece é que a sua trajetória de vida com essa linguagem é modificada por tal acontecimento.

Seu relacionamento com a música foi inaugurado bem antes desse episódio. De fato, tal evento provoca uma interrupção de sua prática musical, uma espécie de luto. Entretanto, em um momento posterior e, com o apoio de seus amigos e de sua mãe, ela retoma sua prática musical em sua Igreja, sendo até certo ponto, uma válvula de escape, um caminho para sua recuperação e superação de tal circunstância.

Conforme ela relata, seu tio não possuía habilidades musicais evidenciadas, ou seja, não cantava e não tocava nenhum instrumento musical. Quando indagada acerca da relação entre o falecimento de seu tio e de seu interesse pela música, ela assim responde:

Eu não consigo explicar o porquê. Porque tipo assim, eu cantava na Igreja, eu só vivia na Igreja cantando. Aí no dia que eu descobri que ele tinha falecido, aí eu parei de cantar. Eu já cantava, aí eu parei de cantar e passei um bom tempo sem cantar, sem ir para a Igreja. Aí as meninas perguntavam porque eu não ia mais para a Igreja, ai eu me afastei. Aí quando a mãe foi dizendo B volta a cantar, volta a Igreja, ai eu fui né, voltei a Igreja e comecei a cantar novamente. Mas toda vez quando eu vou cantar eu sempre tenho que me lembrar dele. Porque tipo assim, teve um dia que eu fui para a Igreja, ai ele estava em casa, ai eu já tinha tomado banho, aí ele estava se despedindo já, ele estava abraçando todo mundo, beijando todo mundo, falando que ia embora, não sei o quê. Aí ele queria me abraçar, aí eu disse assim, não tio, não me abraça não. Aí ele disse assim, por quê? Aí eu disse assim, porque tu tá sujo. Eu já ia para a Igreja. Aí a mãe disse assim, B, o que é isso? Eu disse assim, não mãe é porque ele tá sujo e eu tenho que ir para a Igreja. Porque ele era tipo assim, ele bebia né. Aí ele foi arrastado por um carro, aí foi por isso que ele morreu. Aí ele ficou tão triste. Aí quando foi no outro dia, quando eu cheguei da Igreja, no outro dia, disseram que ele tinha falecido. Então, ele se despediu de todo mundo. Ele só não se despediu de mim porque eu rejeitei ele. Aí isso ai me tocou muito, é por isso que toda vez que eu canto eu me lembro do que eu fiz, entendeu? Do que eu fiz com ele.

\footnotetext{
${ }^{3}$ De acordo com o site Estudo Prático, a vaquejada consiste na ação que envolve um boi solto em uma arena e dois vaqueiros montados em um cavalo que tentam derrubar o animal pela calda dele. Disponível em: $<$ https://www.estudopratico.com.br/o-que-e-a-vaquejada-e-qualsua-origem/>. Acessado em 09/07/2018.
} 
É possível ver que há um arrependimento em sua fala, e, que tal pesar é o propulsor para que essa memória aflore quando a mesma esteja a cantar uma canção. Desta maneira, fica evidente que é um fato importante em sua trajetória de vida e formação musical.

No entanto, conforme já apresentado, apesar de tamanha importância que a colaboradora confere a esse capítulo de sua história, nesse mesmo trecho ela revela que seu relacionamento com a música é anterior a esse episódio. Assim, ela apresenta que já cantava em sua Igreja.

Tal colaboradora possui um irmão mais velho que toca violão e que também canta. Durante a entrevista ela expõe que sua prática com a música é iniciada junto a esse irmão, cantando junto com ele na Igreja: "meu irmão canta, ele se garante cantar, ele cantava comigo, ele sabe tocar violão.”. Assim, é possível compreender que o seu interesse pela música surge em sua prática religiosa, para ser cantora em seu local de culto.

Pois é, porque ele não é assim desses cantores. Ele cantava comigo porque ele cantava na Igreja. Agente (sic) cantava na Igreja juntos, eu e ele. Mais ai depois ele se afastou de mim, ai eu tive que começar a cantar sozinha porque ele vendeu o violão dele, aí eu fiquei sem violão. Porque ele tocava para mim né.

A referida informante aponta que a ausência de oportunidades, fato também relatado pela outra entrevistada, foi um empecilho em sua trajetória de vida e formação musical, sendo esse um ponto semelhante em ambas as trajetórias aqui apresentadas, a dificuldade do acesso à educação musical.

Conforme a informante B nos apresenta, sua cidade, ou melhor, seu campo de origem é bem restrito de oportunidades, sendo bem mais desassistido que o bairro em que passou a residir durante o curso dessa investigação. Assim, ela nos falou sobre seu local de infância "porque lá é tipo um lugar assim deserto assim, que ninguém liga para lá. Lá, onde eu morava é isolado, não tem essas coisas como tem em Fortaleza, como aqui eu vou encontrar muita oportunidade.".

Apesar de sua esperança acerca das oportunidades que poderia encontrar em Fortaleza, a informante A nos mostrou que não é tão simples, que o acesso ao conhecimento musical ainda é difícil de ser conseguido gratuitamente em Fortaleza: "a professora começou até certo tempo dar aula e tal, aí parou. Aí nós paramos de ir para o projeto. Aí passou um tempo, aí chegou outro, esse passou eu acho que uns sete meses e saiu novamente, não deu nem satisfação.". Como pode ser visto nesse trecho de entrevista, a continuidade das ações é um dificultador à educação musical nessa cidade.

Assim como a entrevistada A, B recebeu estímulos negativos em sua caminhada, ela nos relatou que haviam shows de calouros em sua escola e que nunca participou por não sentir-se confortável em participar, uma vez que ela sentia ser hostil o ambiente de tal evento, pois era comum os outros estudantes vaiarem os colegas que estavam se apresentando: "eu nunca tive oportunidade porque eu me prendia, eu não conseguia cantar, porque lá na minha escola se agente (sic) pelo menos cantasse errado o povo já começava a vaiar, aí tipo, eu me prendia com vergonha".

Como já apresentado, essa mudança de campo trouxe uma esperança para tal informante. Expectativa não só de oportunidades, mas também de liberdade. Enquanto ela sentia-se intimidada a realizar suas práticas musicais em sua escola anterior, ela nos expõe que em sua nova escola ganhou ânimo e coragem para realizar tal prática: "aí quando eu cheguei aqui, eu já me senti mais assim, que eu podia cantar, que eu podia ter oportunidade aqui, como eu não tive lá aonde (sic) eu morava".

No entanto, a timidez e o receio dessa informante cantar em público é algo que está incorporado ao seu habitus, uma vez que, essa insegurança é como uma sombra que lhe persegue. Talvez já tenham acontecido fatos que geraram uma espécie de "trauma" nesta colaboradora, pois, ela relata: "eu não sei, porque eu acho que o povo vão rir de mim, vão tirar brincadeira, aí eu tenho vergonha de me expor, de cantar. Pode eu errar e aí as pessoas começar a falar baixinho, começar a gritar, por isso eu tenho vergonha de cantar em público." E esses desestímulos não ocorreram só em sua escola, até em seu seio familiar, que 
já foi apresentado como um local inspirador, houve momentos de falta de incentivo, ou, podemos até dizer, de fomento à desistência por parte da entrevistada. Ela nos relata momentos em que sua mãe não gostava de sua prática musical, chegando a dizer que era uma coisa que não seria para essa informante:

Aí a minha mãe, assim, até a pobre réia não achava muito bom né, porque eu só comecei a gostar de música depois que meu tio faleceu. Porque ai eu me toquei assim, quando eu escutava música aí eu começava a cantar, a mãe ficava brigando comigo, porque não dava para mim, porque essas músicas, música não combinava comigo.

Assim como a colaboradora A, a entrevistada B também exprimiu desejos de seguir carreira musical. Ela revela em sua entrevista que "eu queria, para mim né, se eu me formasse bem, eu queria né ser uma cantora mas... deixa eu ver como eu posso dizer... ser uma cantora. Normal. Que o povo me conhecesse, que eu tirasse a timidez, que eu conhecesse as pessoas, entendeu?". Além de cantar a referida informante possui o desejo de aprender a tocar violão. Assim ela responde: "violão, por que tenho vontade de cantar e tocar".

Fica evidente que as duas colaboradoras possuem em suas trajetórias de vida e formação musical pontos convergentes, apesar de estarem inseridas em campos sociais distintos, bem como possuem diferenças nesses processos.

É evidente a influência que a família exerceu na aquisição do capital musical da informante A. Sem o primeiro contato com o violão na casa de seu avô, talvez, sua história de vida e formação musical teria tomado caminhos distintos dos até aqui trilhados. Através da entrevista e dos questionários não foi possível saber se havia um desejo por parte de seu avô em aprender a tocar tal instrumento, o que o levou a possuir tal equipamento de música. Entretanto, sabemos que ele ganhou relevância como capital herdado de A.

Conforme a entrevistada A relatou, em sua família só existe mais uma pessoa que possui habilidades com música reconhecível, a saber: sua irmã mais nova. De acordo com ela, sua irmã canta. Questionei sobre como sua irmã começou a cantar, a estudar canto, se tinha sido em algum lugar - ONG, Igreja, Escola - e assim ela responde "ela não canta em Igreja, tipo assim e nem nada, é dela mesmo. A voz dela você não tem do que reclamar. É perfeita. Só que ela tem que estudar por conta do vocal, né? Tem que ter afinação, tempo, essas coisas assim que ela não sabe ainda. Mas a voz dela é fina".

É interessante que a fala da informante, de certa forma, traz elementos que possuem uma certa proximidade com a ideia do senso comum aqui já discutido, no qual a música é algo que nasce junto com a pessoa, é inato ao ser, portanto é um dom. No entanto, após ela afirmar que tal prática musical é natural de sua irmã, ela torna a apresentar a importância da formação musical, de uma educação musical no aprendizado da música. Desta forma, ela finaliza seu discurso apresentando que somente com o estudo de técnicas vocais é que sua irmã irá aprender elementos básicos, tais como afinação e andamento. É evidente que tal informante possui um afeto e um apreço grande pelo timbre de voz de sua irmã, ao ponto de classificar tal voz como "perfeita". Ela ainda revela que a voz de sua irmã é fina, assim, talvez a informante A se agrade com vozes agudas.

Tal informante revelou que seus pais, tios, avós e primos nunca tiveram nenhuma prática com música além da escuta. No entanto, ela expõe que seus parentes gostam bastante de apreciar essa arte dos sons, de modo que, a música é presente em seus cotidianos.

A informante B, por sua vez, não nos forneceu muitas informações acerca das relações entre seus familiares e a música. Entretanto, os poucos dados que puderam ser coletados sobre tal aspecto nos levam à compreensão de que dois de seus parentes foram cruciais na formação de seu habitus, seu irmão e seu tio.

O irmão, como já foi apresentado, auxiliou tal informante no início de sua trajetória musical, fornecendo-lhe referência e subsídios para cantar, sempre estando ao seu lado em seus momentos de prática musical. É verdade que, sem o violão de seu irmão, talvez essa relação com a música não tivesse ganhado o relevo apresentado pela informante.

Já seu tio, foi um divisor de águas. Seu relacionamento com tal arte fica mais intenso após o falecimento deste parente. Ele não ensinou música a tal colaboradora. Ele sequer sabia tocar algum instrumento musical e/ou cantar, como ela 
mesmo me revelou. Entretanto, as práticas em música serviram de mola propulsora para impulsionar tal informante a superar a morte de seu tio e encerrar seu luto. Assim, o parente não influencia sua formação musical, mas serve de incentivo para acentuar a relação de tal colaboradora com essa arte.

Assim como a informante A, B não possui nenhum parente que possua habilidades com música, além de seu irmão. Entretanto, através de sua narrativa fica demonstrado que a música, talvez, não seja uma coisa presente nos cotidianos de seus familiares, pois a mesma me expõe que seu namorado e sua tia, com quem reside, possuem um certo incômodo com o fato de tal colaboradora escutar bastante tempo de música e gostar de cantar na maior parte do seu dia, durante quase todas as suas atividades cotidianas.

\section{Considerações Finais}

Por meio desse estudo, conhecemos alguns aspectos das trajetórias de vida e formação musical das duas adolescentes que colaboraram com essa pesquisa. Foi através de suas memórias e narrativas sobre seus processos de formação musical que conseguimos reconstituir seus itinerários formativos, e assim, identificamos e conhecemos os campos nos quais estiveram inseridas, os capitais que foram acumulados e incorporados por elas, enfim, um habitus - constituído e incorporado.

Ao conhecermos o relacionamento das informantes com a música, ficou evidente que tal forma artística assumiu um papel fundamental em suas vidas, sendo, para elas, um importante capital. Desta forma, ao longo de suas trajetórias, elas herdaram e acumularam capitais musicais, únicos para cada uma delas, que influenciaram e definiram seus percursos de formação musical.

A família mostrou-se fundamental nessas trajetórias de vida, pois, foi por meio dos eventos que aconteceram em seus campos familiares que seus percursos de formação ganharam tais contornos. Ficou evidente também que o incentivo ou a falta de incentivo são capitais que, de alguma maneira, impactaram esses processos.

Ambas as informantes incorporaram, até certo ponto, capitais sócio-musicais que as levaram de alguma maneira a compreender que as habilidades com música possuem alguma vinculação com a ideia de dom musical. Apesar delas terem suplantado em inúmeros momentos essa concepção, em algumas ocasiões, tal concepção ainda foi presente.

É importante, em estudos futuros, serem investigados como a ideia do dom musical e/ou predisposição para a música interferem no habitus, pois, é possível que muitas pessoas não consigam alcançar a prática musical e/ou criem diversos bloqueios ao incorporar esse capital.

Também ficou evidenciado que não existe uma prática de formação musical eficiente dentro dos sistemas escolares, aos quais as entrevistadas possuíam vínculos ao curso de suas trajetórias, comprovando, desta maneira, a ineficácia dos sistemas escolares nesses processos formativos e sua inoperância para o surgimento do interesse pela música. Também ficou evidente que outros equipamentos com propostas educativas, assim como, a indústria da cultura auxiliam o surgimento e o início dessas trajetórias de aquisição dos conhecimentos musicais. Desta forma, é importante que estudos sejam realizados com o objetivo de compreender como a música é ou pode ser inserida na educação escolar, e, qual o papel das práticas musicais na formação educacional.

\section{Referências}

Abreu, Y. P. de, \& Viana Júnior, G. S. (2018). Habitus e formação musical de adolescentes: um estudo com estudantes da escola pública. Retrieved May 31, 2021, from http://www.repositorio.ufc.br/bitstream/riufc/35877/3/2018_dis_ypabreu.pdf.

Adorno, T. W., \& Horkheimer, M. (1985). Dialética do esclarecimento: fragmentos filosóficos (G. A. de Almeida, Trad.). Rio de Janeiro: Zahar.

Bogdan, R. C., \& Biklen, S. K. (1994). Investigação qualitativa em educação: uma introdução à teoria e aos métodos (M. J. Alvarez, S. B. dos Santos, T. M. Baptista, Trad.). Porto: Porto Editora. 
Research, Society and Development, v. 10, n. 7, e12710716376, 2021

(CC BY 4.0) | ISSN 2525-3409 | DOI: http://dx.doi.org/10.33448/rsd-v10i7.16376

Bourdieu, P. (2011a). A Distinção : a crítica social do julgamento (D. Kern, G. J. F. Teixeira, Trad) (2ª Ed.). Porto Alegre: Zouk.

Bourdieu, P. (2013). A economia das trocas simbólicas (S. Miceli Org) (7ª Ed.). São Paulo: Perspectiva.

Bourdieu, P. (2009). O senso prático (M. Ferreira, Trad.). Petrópolis: Editora Vozes.

Bourdieu, P. (2011b). Razões práticas : Sobre a teoria da ação (M. Corrêa, Trad) (11 $1^{\mathrm{a}}$ Ed.). Campinas: Papirus.

Gil, A. C. (2009). Métodos e técnicas de pesquisa social (6 $6^{\text {a }}$ Ed.). São Paulo: Atlas.

Godoy, A. S. (1995). Introdução à pesquisa qualitativa e suas possibilidades. Revista de administração de empresas, volume 35, número 2, p. 57-63. Retrieved July 18, 2017, from https://goo.gl/W3H1HS.

Matos, E. de A. (2008). Um inventário luminoso ou alumiário inventado: uma trajetória humana de musical formação. Fortaleza: Diz Editor(a)ção.

Morin, E. (2011). Culturas de massas no século XX: espírito do tempo 1: neurose (M. R. Sardinha, Trad) (10ª Ed.). Rio de Janeiro: Forense Universitária. 